\title{
An apolar extract of Critonia morifolia inhibits c-Myc, cyclin D1, Cdc25A, Cdc25B, Cdc25C and Akt and induces apoptosis
}

\author{
CHRISTINE UNGER ${ }^{1}$, RUXANDRA POPESCU ${ }^{2}$, BENEDIKT GIESSRIGL $^{1}$, LUCIE RAROVA $^{3}$, IRENE HERBACEK $^{4}$, \\ MAREIKE SEELINGER $^{1}$, RENE DIAZ ${ }^{5}$, BRUNO WALLNÖFER ${ }^{6}$, MONIKA FRITZER-SZEKERES $^{7}$, \\ THOMAS SZEKERES ${ }^{7}$, RICHARD FRISCH ${ }^{5}$, KAREL DOLEŽAL ${ }^{3}$, MIROSLAV STRNAD $^{3}$, \\ RAINER DE MARTIN $^{8}$, MICHAEL GRUSCH ${ }^{4}$, BRIGITTE KOPP ${ }^{2}$ and GEORG KRUPITZA ${ }^{1}$
}

${ }^{1}$ Institute of Clinical Pathology, Medical University of Vienna, Waehringer Guertel 18-20; ${ }^{2}$ Department of Pharmacognosy, Faculty of Life Sciences, University of Vienna, Althanstrasse 14, Austria; ${ }^{3}$ Centre of the Region Haná for Biotechnological and Agricultural Research, Faculty of Science, Palacký University, Šlechtitelů 11, 78371 Olomouc, Czech Republic;

${ }^{4}$ Department of Medicine I, Division: Institute of Cancer Research, Comprehensive Cancer Center, Medical University Vienna, Borschkegasse 8a, A-1090 Vienna, Austria; ${ }^{5}$ Institute for Ethnobiology, Playa Diana, San José/Petén, Guatemala;

${ }^{6}$ Department of Botany, Museum of Natural History, Burgring 7, A-1010 Vienna; ${ }^{7}$ Clinical Institute of Medical and Chemical Laboratory Diagnostics, ${ }^{8}$ Department of Vascular Biology and Thrombosis Research,

Medical University of Vienna, Waehringer Guertel 18-20, A-1090 Vienna, Austria

Received December 19, 2011; Accepted February 22, 2012

DOI: $10.3892 /$ ijo.2012.1412

\begin{abstract}
Investigating the bioactivity of traditional medical remedies under the controlled conditions of a laboratory is an option to find additional applications, novel formulations or lead structures for the development of new drugs. The present work analysed the anti-neoplastic activity of increasing polar extracts of the rainforest plant Critonia morifolia (Asteraceae) that has been successfully used as traditional remedy to treat various inflammatory conditions in the long-lasting medical tradition of the Central American Maya, which was here also confirmed in vitro. The apolar petroleum ether extract exhibited the most potent anti-proliferative and pro-apoptotic effects in HL-60 cells and triggered down-regulation of Cdc25C and cyclin D1 within $30 \mathrm{~min}$ followed by the inhibition of c-Myc expression and the onset of caspase- 3 activation within $2 \mathrm{~h}$. Subsequent to these very rapid molecular responses $\mathrm{Chk} 2$ and $\mathrm{H} 2 \mathrm{AX}$ became phosphorylated $(\gamma-\mathrm{H} 2 \mathrm{AX})$ after $4 \mathrm{~h}$. Analysis of the cell cycle distribution showed an accumulation of cells in the G2-M phase within $8 \mathrm{~h}$ and after $24 \mathrm{~h}$ in S-phase. This was temporally paralleled by the down-regulation of Cdc25A, Cdc25B, Wee1 and Akt. Therefore, the attenuation of cell cycle progression in the G2-M phase was consistent with the known role of Chk2 for G2-M arrest and with the role of $\mathrm{Cdc} 25 \mathrm{~B}$ in $\mathrm{S}$-phase progression. These
\end{abstract}

Correspondence to: Dr Georg Krupitza, Institute of Clinical Pathology, Medical University of Vienna, Waehringer Guertel 18-20, A-1090 Vienna, Austria

E-mail: georg.krupitza@meduniwien.ac.at

Key words: Critonia morifolia, Cdc25, cyclin D1, Akt, anti-neoplastic, healing plant findings suggest the presence of two distinct active principles in the petroleum ether extract of $C$. moriflia. These facilitated the strong apoptotic response evidenced by the rapid activation of caspase-3 that was later enforced by the inhibition of the survival kinase Akt. Importantly, the efficient down-regulation of Akt, which is successfully tested in current clinical trials, is a unique property of C. morifolia.

\section{Introduction}

Cancer is one of the leading causes of death worldwide. For 2010, the United States National Institute of Cancer estimates approximately 1.5 million new cases of cancer and more than 500,000 deaths from cancer in the USA (www.cancer.gov). Apart from avoidable risks such as smoking, the most important risk factor for cancer is supposed to be the increase in life expectancy, since most cancers occur in people over the age of 65 . However, also younger adults and children are diagnosed with cancer. Thus, there exists a constant need for the development of novel anti-neoplastic agents. Natural products represent a vital resource for therapeutic principles. Like vincristine, more than $60 \%$ of all drugs used in Western medicine originate from natural sources including plants, microorganisms and marine organisms (1). Moreover, approximately $80 \%$ of the world's population relies on medical plants for their primary health care, especially in less-developed countries. As a result, numerous traditional healing plants successfully passed hundreds and even thousands of years of application in a variety of diseases. The big advantage of natural products is that they comprise a vast diversity of complex structures, whereas synthetic libraries typically show considerably less diversity (2). Although the probability to find new chemotypes from terrestrial plants is low (3) plant derived drugs have frequently shown novel mechanisms of action. Therefore, plant secondary metabolites need 
to be investigated in bio-activity guided assays and also crude extracts that are potent in vitro should be tested in vivo at an early stage of lead compound discovery (4). The screening of natural products encompasses the high probability of duplication, i.e., the isolated active compound might be already known and thus cannot be patented (5). This and the problem of reliable access and supply make drug development from natural sources less attractive to pharmaceutical industries. Therefore, the study of healing- and other plants or organisms has remained with the academic institutions like universities, because they focus less on commercial profits. The traditional medicine of the Maya of Guatemala/Belize is based on the rich biodiversity of the rain forest, and is still practiced effectively to cure a variety of diseases. In the present work the ethno-medicinal plant Critonia morifolia (Asteraceae), which is still used as anti-inflammatory remedy, was selected for the investigation of its anti-neoplastic properties, because during inflammation and in cancer cells similar signalling pathways are commonly up-regulated. The genus Critonia (Asteraceae) comprises 43 species and is spread from Mexico to Argentina (6). C. morifolia grows as herbaceous shrub up to four meters tall and is found in forests and at the edges of forests, riversides and roadsides.

As a remedy the leaves are applied as steam bath in cases of swelling, retention of fluids, rheumatism, arthritis, paralysis, and muscle spasms. Baths of boiled leaves alone or in combination with other healing plants are used to cure skin conditions, wounds, insomnia, flu and aches. Boils, cysts, pus-filled sores and severe skin damages with uncontrolled wound tissue growth (cancer) are treated with leaves that were heated in oil prior to direct application on the swelling (7). Despite of its curative uses as home remedy only limited phytochemical and no pharmacological data were published so far and therefore, the data presented here are unprecedented for this plant.

\section{Materials and methods}

Antibodies. Antibodies against: Chk1 (2G1D5, no. 2360), phospho-Ser345 Chk1 (no. 2341), Chk2 (no. 2662), phosphoThr68 Chk2 (no. 2661), cleaved Asp175 caspase-3 (no. 9661), Wee1 (no. 4936), phospho-Ser462 Weel (D47G5, no. 4910), phospho-Ser473 Akt (587F11, no. 4051), Akt (no. 9272) and phospho-Tyr15 Cdk1 (Cdc2, 10A11) were from Cell Signaling (Danvers, MA, USA), PARP-1 (F-2, sc-8007), Cdc25A (F-6, sc-7389), Cdc25B (C-20, sc-326), Cdc25C (C-20, sc-327), Cdk1 (Cdc2,p34, 17, sc-54), cyclin D1 (M-20, sc-718), p21 (C-19, sc-397) from Santa Cruz Biotechnology (Santa Cruz, CA, USA), c-Myc Ab-2 (9E10.3, no. MS-139-P1) fromThermo Fisher Scientific (Fremont, CA, USA), phospho-Ser177 Cdc25A (no. AP3046a) from Abgent (San Diego, CA, USA), phospho-Ser139 H2AX (DR 1017) from Calbiochem (San Diego, CA, USA), phosphorSer75 Cdc25A (ab47279) from Abcam (Cambridge, UK), and $\beta$-actin (AC-15, A5441) was from Sigma (St. Louis, MO, USA). The secondary antibodies peroxidase-conjugated anti-rabbit IgG and anti-mouse IgG were purchased from Dako (Glostrup, Denmark).

Plant material. The aerial parts (leaves, caulis, florescence) of $C$. morifolia [vernacular names: Palo verde, YAAX (ItzáMaya)] were collected in Guatemala, Departamento Petén, at the north-western shore of Lago Petén Itzá, San José, $0.5 \mathrm{~km}$
NNE Zentrum from San José to La Nueva San José (16 59'16" N, 89 53'45" W). Voucher specimens (leg. G. Krupitza \& R.O. Frisch, no. 8-2009 28. 04. 2009, Herbarium W, det. R.O. Frisch) were archived at the Museum of Natural History, Vienna, Austria.

Plant extraction by accelerated solvent extraction (ASE 2000). Lyophilized leaves (22.5 g) of $C$. morifolia were powdered and mixed 2:1 with diatomaceous earth, which acts as a dispersant and drying agent, prior to subjecting the sample to sequential extraction with five solvents of increasing polarity (petroleum ether, dichloromethane, ethyl acetate, methanol and water). The extractions were performed at 150 bar and $40^{\circ} \mathrm{C}$ using an ASE 2000 accelerated solvent extractor and a solvent controller (Dionex, Sunnyvale, CA, USA). The scheme of each run of extraction was as follows: 5 min heating, 2 min static at 150 bar and $40^{\circ} \mathrm{C}, 10 \mathrm{sec}$ flushing and 2 cycles of purging for $60 \mathrm{sec}$. For each solvent cycle, the solid plant material that remained in the ASE cells after the extractions was flushed with the respective cold solvent (which was pooled accordingly) and dried with nitrogen gas. Then, gained extracts were subjected to rotary evaporation.

Extract yields and stock calculation. The extract weights obtained from serial extraction calculated for $1 \mathrm{mg}$ lyophilized C. morifolia leaves are presented in Table I. To determine the anti-proliferative effect of the extracts, HL-60 cells were treated with increasing concentrations $(5,15,30$ and $60 \mu \mathrm{g} / \mathrm{ml})$. The activity of the apolar extract was rather unstable and therefore, the dried extract was always prepared fresh before each experiment. For all other samples the DMSO concentration was adjusted to $0.5 \%$ (final concentration).

Cell culture. HL-60 (human promyelocytic leukemia cell) cells were purchased from American Type Culture Collection (ATCC). The cells were grown in RPMI-1640 medium which was supplemented with $10 \%$ heat-inactivated fetal calf serum (FCS), $1 \%$ Glutamax and $1 \%$ penicillin-streptomycin. Both, medium and supplements were obtained from Life Technologies (Carlsbad, CA, USA). Human umbilical vein endothelial cells (HUVECs) were isolated and cultured in M199 medium supplemented with 20\% fetal calf serum (FCS), antibiotics, endothelial cell growth supplement and heparin as previously described (8). The cells were kept at $37^{\circ} \mathrm{C}$ in a humidified atmosphere containing $5 \% \mathrm{CO}_{2}$.

SELE (CD62E, E-selectin, ELAM)-induction assay. Each well of a 96-well plate was coated with gelatine by applying $200 \mu \mathrm{l}$ of $1.0 \%$ gelatine for $10 \mathrm{~min}$ at room temperature. Outer wells (A1-A12, H1-H12, 1-H1 and A12-H12) contained only $200 \mu \mathrm{l} /$ well medium and served as an evaporation barrier. HUVECs $\left(1 \times 10^{4}\right)$ were seeded in each of the other wells in $200 \mu \mathrm{l}$ medium and grown for $48 \mathrm{~h}$ to optimal confluence. Critonia petroleum ether extract at 10,15 and $20 \mu \mathrm{g} / \mathrm{ml}$ was added to the HUVEC-containing wells in triplicate, and the cells were incubated for $30 \mathrm{~min}$, after which $10 \mathrm{ng} / \mathrm{ml} \mathrm{TNF} \alpha$ was added per well to stimulate NFKB, and thus SELE. After a further 4-h incubation, the levels of SELE in each of the HUVEC-containing wells were determined by enzyme-linked activity assays (ELISAs) as described below. 
Table I. C. morifolia extract weights corresponding to lyophilized plant material and applied in proliferation assays.

\begin{tabular}{|c|c|c|c|}
\hline Extract type & $\begin{array}{l}\text { Extract weight }(\mu \mathrm{g}) \text { corresponding } \\
\text { to } 1 \mathrm{mg} \text { dried plant }\end{array}$ & $\begin{array}{l}\text { Extract final concentration } \\
\qquad(\mu \mathrm{g} / \mathrm{ml} \text { medium })\end{array}$ & $\begin{array}{l}\text { Corresponding dried } \\
\text { plant weight }(\mu \mathrm{g})\end{array}$ \\
\hline
\end{tabular}

Petroleum ether

Dichloromethane

28

59

5

15

30

60

5

15

30

60

14

Ethyl acetate

140

Methanol

5
15
30
60

5

1071.3

2142.6

4285.2

214.2

30

428.4

Water

184
35.7

107.1

84.7

508.2

1016.4

178.6

535.8

1071.6

2143.2

27.2

81.5

163.0

326.0
Cell-surface ELISA SELE: Cells were washed once with PBS and fixed with $100 \mu \mathrm{l} /$ well $25 \%$ glutaraldehyde [40 $\mu \mathrm{l}$ in $10 \mathrm{ml}$ PBS, Sigma-Aldrich (Munich, Germany), stored at $-20^{\circ} \mathrm{C}$ in aliquots] for $15 \mathrm{~min}$ at room temperature. Then, cells were washed 3x with $200 \mu \mathrm{l}$ per well PBS/0.05\% Tween-20, blocked with $200 \mu \mathrm{l} /$ well $5 \%$ BSA/PBS for $1 \mathrm{~h}$, and washed again 3x with $200 \mu \mathrm{l}$ per well PBS/0.05\% Tween-20. Then, anti-SELEantibody (clone BBA-1, R\&D Systems, Minneapolis, MN, USA) diluted 1:5000 in 0.1\% BSA/PBS (100 $\mu \mathrm{l}$ per well) was added for $1 \mathrm{~h}$ at room temperature and washed thereafter $5 \mathrm{x}$ with $200 \mu \mathrm{l}$ per well PBS/0.05\% Tween-20. Subsequently, goat anti mouse-HRP antibody (Sigma-Aldrich, Munich, Germany) diluted 1:10000 in $0.1 \% \mathrm{BSA} / \mathrm{PBS}$ (100 $\mu \mathrm{l}$ per well) was applied and the cells were incubated for a further $1 \mathrm{~h}$ in the dark at room temperature and, after decanting, washed five times with $200 \mu \mathrm{l}$ per well PBS/0.05\% Tween-20. The HRP-activity of the cells in each of the wells was estimated using Fast-OPD (o-phenylenediamine dihydrochloride) (Sigma-Aldrich, Munich, Germany) assay and absorbance was measured at $\mathrm{OD}_{492 \mathrm{~nm}}$ in a vertical spectrophotometer.

Cytotoxicity testing: For the SELE expression assay the toxicity of the petroleum ether extract was assessed in HUVECs by Calcein AM cytotoxicity assays in 96-well microtitre plates. Portions $(20 \mu \mathrm{l})$ of the extract concentrations were added in triplicate to the cells, which were then incubated at $37^{\circ} \mathrm{C}$ in an atmosphere containing $5 \% \mathrm{CO}_{2}$ for $4 \mathrm{~h}$, after which Calcein $\mathrm{AM}$ solution (Molecular Probes, Invitrogen, Karlsruhe, Germany) was added for $1 \mathrm{~h}$ according to the manufacturer's instructions. The fluorescence of viable cells was quantified using a Fluoroscan Ascent instrument (Labsystems, Finland) reader and on the basis of triplicate experiments the cytotoxic concentrations were calculated.

Proliferation assay. HL-60 cells were seeded in 24-well plates at a concentration of $1 \times 10^{5}$ cells $/ \mathrm{ml}$ allowing logarithmic growth within $48 \mathrm{~h}$. Afterwards cells were incubated with increasing concentrations of plant extracts $(5,15,30$ and $60 \mu \mathrm{g} / \mathrm{ml})$ for $48 \mathrm{~h}$. After 24 and $48 \mathrm{~h}$ the cell number was counted using a KX-21 N microcell counter (Sysmex Corp., Kobe, Japan) and the percent of cell divisions compared to the untreated control were calculated as follows: $\left[\left(\mathrm{C}_{48 \mathrm{~h}+\text { drug }}-\mathrm{C}_{24 \mathrm{~h}+\mathrm{drug}}\right) /\left(\mathrm{C}_{748 \text {-drug }}-\mathrm{C}_{24 \mathrm{~h}-\text { drug }}\right)\right]$ $\mathrm{x} 100=\%$ cell division, where $\mathrm{C}_{48 \mathrm{~h}+\text { drug }}$ is the cell number after $48 \mathrm{~h}$ of extract treatment, $\mathrm{C}_{24 \mathrm{~h}+\text { drug }}$ is the cell number after $24 \mathrm{~h}$ of extract treatment, $\mathrm{C}_{48 \mathrm{~h} \text {-drug }}$ and $\mathrm{C}_{24 \mathrm{~h} \text {-drug }}$ are the cell numbers after 48 and $24 \mathrm{~h}$ without extract treatment $(9,10)$.

Apoptosis assay - Hoechst 33258 and propidium iodide double staining. Hoechst 33258 (HO) and propidium iodide (PI) double staining (Sigma, St. Louis, MO) allows the determination of the type of death the cell is undergoing, i.e., apoptosis (early or late) 

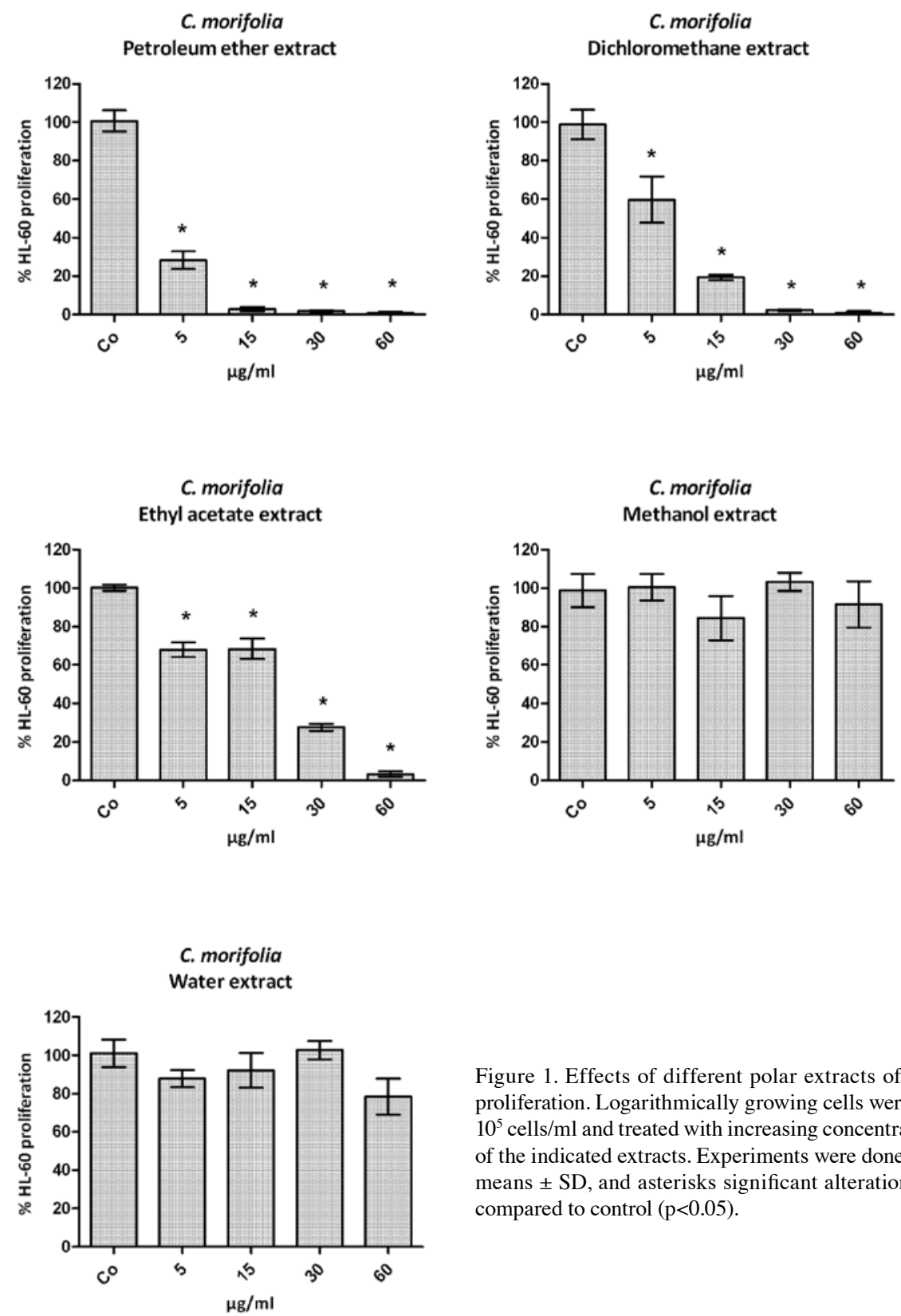

Figure 1. Effects of different polar extracts of $C$. morifolia on HL-60 cell proliferation. Logarithmically growing cells were seeded at a concentration of $10^{5}$ cells $/ \mathrm{ml}$ and treated with increasing concentrations $(5,15,30$ and $60 \mu \mathrm{g} / \mathrm{ml})$ of the indicated extracts. Experiments were done in triplicate. Error bars show means $\pm \mathrm{SD}$, and asterisks significant alterations of proliferation in percent compared to control $(\mathrm{p}<0.05)$.

or necrosis $(11,12)$. HL-60 cells were seeded in a 24 -well plate at a concentration of $1 \times 10^{5}$ cells $/ \mathrm{ml}$ and treated with increasing concentrations of the specified extracts. After a 24-h incubation, $100 \mu \mathrm{l}$ cell suspension of each well were transferred into separate wells of a 96-well plate and Hoechst 33285 and propidium iodide were added at final concentrations of 5 and $2 \mu \mathrm{g} /$ $\mathrm{ml}$, respectively. After a $1-\mathrm{h}$ incubation at $37^{\circ} \mathrm{C}$, stained cells were examined and photographed on a fluorescence microscope (Axiovert, Zeiss, Jena, Germany) equipped with a DAPI filter. Cell death was evaluated and counted by visual examination of the photographs according to the morphological characteristics revealed by HOPI staining. Experiments were performed in triplicate.

Cell cycle distribution analyses by fuorescence activated cell sorting (FACS). HL-60 cells were seeded in T-75 tissue culture flasks at a concentration of $2 \times 10^{5}$ cells $/ \mathrm{ml}$ and treated with 10 and $15 \mu \mathrm{g} / \mathrm{ml}$ of the petroleum ether extract of $C$. morifolia. After
8- and 24-h incubation at $37^{\circ} \mathrm{C}$ cells were harvested, transferred into $15 \mathrm{ml}$ tubes and centrifuged $\left(4^{\circ} \mathrm{C}, 800 \mathrm{rpm}, 5 \mathrm{~min}\right)(13,14)$. The supernatant was discarded and the cell pellet washed with cold PBS (phosphate buffered saline, $\mathrm{pH} 7.2)$, centrifuged $\left(4^{\circ} \mathrm{C}\right.$, $800 \mathrm{rpm}, 5 \mathrm{~min})$, resuspended in $1 \mathrm{ml}$ cold ethanol (70\%), and either fixed for $30 \mathrm{~min}$ at $4^{\circ} \mathrm{C}$, or stored at $-20^{\circ} \mathrm{C}$ prior further handling. After two washing steps with cold PBS, the cell pellet was resuspended in $500 \mu \mathrm{l}$ cold PBS and transferred into a 5-ml polystyrene round bottom tube. RNAse $\mathrm{A}$ and propidium iodide were added to a final concentration of $50 \mu \mathrm{g} / \mathrm{ml}$ and incubated for $1 \mathrm{~h}$ at $4^{\circ} \mathrm{C}$. The final cell number was adjusted between 0.5 and $1 \times 10^{6}$ cells in $500 \mu \mathrm{l}$. Cells were analyzed by FACSCalibur flow cytometer (BD Bioscience, San Jose, CA, USA). Cell cycle distribution was calculated with ModFid LT software (Verity Software House, Topsham, ME, USA).

Western blotting. HL-60 were seeded in T-75 tissue culture flasks at a concentration of $1.8 \times 10^{5}$ cells $/ \mathrm{ml}$ and incubated with 
$15 \mu \mathrm{g} / \mathrm{ml}$ petroleum ether extract. Cells were harvested after 0.5 , 2, 4, 8 and $24 \mathrm{~h}$. Then, cells were washed twice with cold PBS and centrifuged at $1000 \mathrm{rpm}$ for $5 \mathrm{~min}$ at $4^{\circ} \mathrm{C}$. The cell pellet was lysed in a buffer containing $150 \mathrm{mM} \mathrm{NaCl}, 50 \mathrm{mM}$ Tris pH 8.0, 1\% Triton-X-100, $1 \mathrm{mM}$ phenylmethylsulfonyl fluoride (PMSF) and $1 \mathrm{mM}$ protease inhibitor cocktail (PIC) (Sigma, Schnelldorf, Germany). The lysate was centrifuged at $12000 \mathrm{rpm}$ for $20 \mathrm{~min}$ at $4^{\circ} \mathrm{C}$. Supernatant was transferred into a $1.5-\mathrm{ml}$ tube and stored at $-20^{\circ} \mathrm{C}$ until further analysis. Equal amounts of protein lysate were mixed with SDS (sodium dodecyl sulfate) sample buffer and loaded onto a $10 \%$ polyacrylamide gel. Proteins were separated by polyacrylamide gel electrophoresis (PAGE) at $120 \mathrm{~V}$. Thereafter proteins were electro-transferred onto a PVDF (polyvinylidene difluoride) membrane (Hybond, Amersham, UK) at $95 \mathrm{~V}$ for $80 \mathrm{~min}$. Membranes were allowed to dry for at least $30 \mathrm{~min}$ up to $2 \mathrm{~h}$ to provide fixing of the proteins to the membrane. Methanol was used to remoisten the membranes. Equal sample loading was checked by staining the membrane with Ponceau S (Sigma). After removing Ponceau S with PBS or TBS (Tris-buffered saline, $\mathrm{pH}$ 7.6), membranes were blocked in PBS- or TBS-milk (5\% non-fat dry milk in PBS containing $0.5 \%$ Tween-20 or TBS containing $0.1 \%$ Tween-20) for $1 \mathrm{~h}$. Then, membranes were washed with PBS/T (PBS containing $0.5 \%$ Tween-20) or TBS/T (TBS containing $0.1 \%$ Tween-20), changing the washing solution 4-5 times, for at least $20 \mathrm{~min}$. Next, membranes were incubated with the primary antibody in blocking solution (according to the data sheet TBS-, PBS-milk or TBS-, PBS-BSA) diluted 1:500-1:1000, gently shaking at $4^{\circ} \mathrm{C}$, overnight. Thereafter, membranes were washed again with PBS/T or TBS/T and incubated with the secondary antibody (peroxidase conjugated anti-rabbit IgG or anti-mouse IgG) diluted 1:2000 in PBS- or TBS-milk at room temperature for $1 \mathrm{~h}$. Chemiluminescence was developed by ECL detection kit (Amersham, UK) and membranes were exposed to Amersham Hyperfilm.

Statistical analyses. For statistical analyses Excel 2003 software and Prism 5 software package (GraphPad, San Diego, CA, USA) were used. The values were expressed as mean \pm standard deviation and the Student's t-test was applied to compare differences between control samples and treatment groups. Statistical significance level was set to $\mathrm{p}<0.05$.

\section{Results}

Apolar C. morifolia extracts inhibit HL-60 cell proliferation. Increasing concentrations of $C$. morifolia extracts were tested in logarithmically growing HL-60 cells. The inhibition of cell proliferation upon treatment with extracts is illustrated in Fig. 1. Petroleum ether extract $(5 \mu \mathrm{g} / \mathrm{ml})$ inhibited growth by $>50 \%$. The dichloromethane- and the ethyl acetate extracts showed a dose-dependent response however, both were less active than the petroleum ether extract. When taking the corresponding dried plant weight into account (Table I), the petroleum ether extract and the dichloromethane extract were the most effective ones. The methanol and the water extracts did not show strong effects on HL-60 proliferation. The petroleum ether extract, as the most active one, was studied in more detail by FACS analyses and western blotting to gain further insights into the underlying mechanisms of growth inhibition.
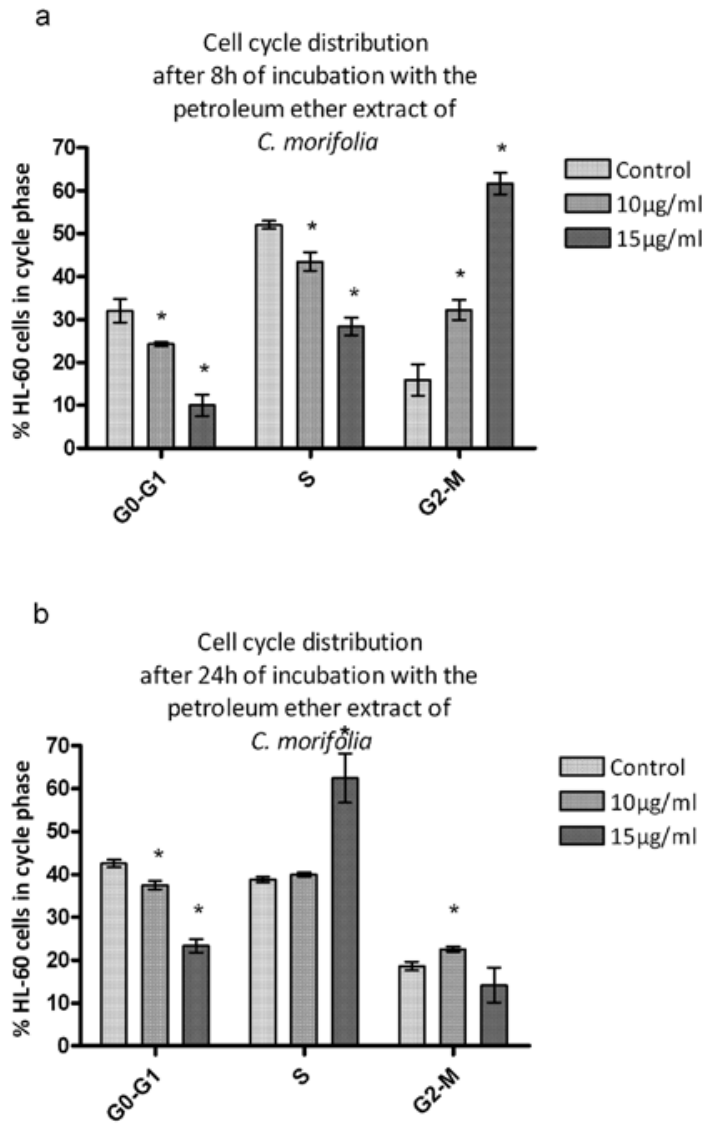

Figure 2. Analysis of cell cycle distribution in HL-60 cells. HL-60 cells $\left(1.8 \times 10^{5}\right.$ cells $\left./ \mathrm{ml}\right)$ were incubated with 10 and $15 \mu \mathrm{g} / \mathrm{ml}$ of the petroleum ether extract of C. morifolia, harvested after (a) $8 \mathrm{~h}$ and (b) $24 \mathrm{~h}$, and subjected to FACS analysis. Error bars indicate means \pm SD, and asterisks significant alterations of cell distributions in the respective cell cycle phases compared to control $(\mathrm{p}<0.05)$. Experiments were performed in triplicate.

The petroleum ether extract induces G2/M and $S$-phase arrest in $H L-60$ cells. HL-60 cells were incubated with 10 and $15 \mu \mathrm{g} / \mathrm{ml}$ petroleum ether extract of $C$. morifolia for 8 and $24 \mathrm{~h}$ and then subjected to FACS analyses. Interestingly, the extract exhibited distinct effects depending on the duration of treatment. After $8 \mathrm{~h}$, the cell population in G2-M phase increased from 15.9 to $32.3 \%$ $(10 \mu \mathrm{g} / \mathrm{ml})$ and up to $61.3 \%(15 \mu \mathrm{g} / \mathrm{ml}$; Fig. 2a) upon extract treatment. The dose-dependent accumulation of HL-60 cells in G2-M was caused at the expense of both G0-G1 cells (from 32.0 to $24.2 \%$ and $10.0 \%$ ) and S-phase cells (from 52.1 to $43.5 \%$ and $28.4 \%$ ). By contrast, treatment with $15 \mu \mathrm{g} / \mathrm{ml}$ extract for $24 \mathrm{~h}$ resulted in S-phase accumulation of $62.4 \%$ of the cells (compared to $38.8 \%$ control cells; Fig. 2b) mainly at the expense of cells in G0-G1 phase, which was reduced from 42.6 to $23.3 \%$. The incubation of HL-60 cells with $10 \mu \mathrm{g} / \mathrm{ml}$ extract exhibited only a slight shift of cell population from G0-G1 to G2-M whereas S-phase remained unchanged. Therefore, $15 \mu \mathrm{g} / \mathrm{ml}$ petroleum ether extract was applied in the following experiments.

Modulated expression of cell cycle regulatory proteins by petroleum ether extract treatment. The transient G2-M cell accumulation after $8 \mathrm{~h}$ and the subsequent arrest in S-phase caused by the petroleum ether extract were studied in further detail by investigating modulations of key proteins of cell cycle regulation. Prominent regulators of cell cycle transit are the 


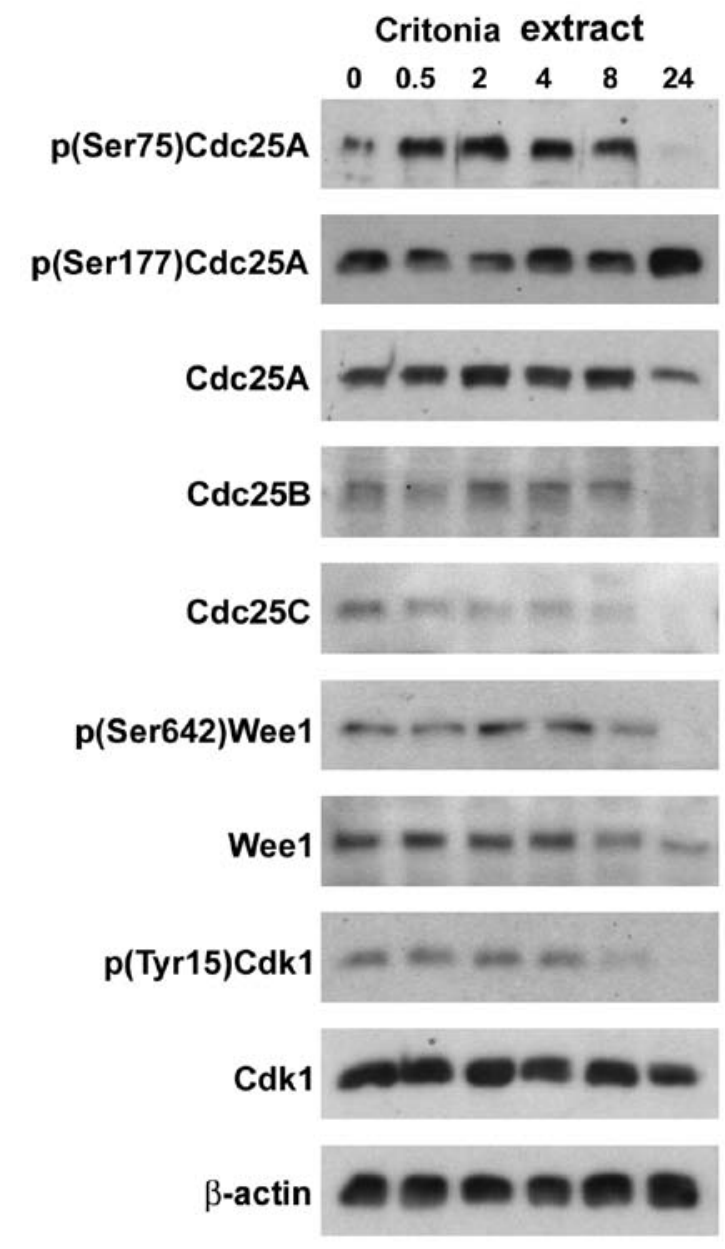

Figure 3. Alteration in the expression of cell cycle regulatory proteins in HL-60 cells. HL-60 cells $\left(1.8 \times 10^{5}\right.$ cells $\left./ \mathrm{ml}\right)$ were treated with $15 \mu \mathrm{g} / \mathrm{ml}$ petroleum ether extract of C. morifolia and after 0.5, 2, 4, 8 and $24 \mathrm{~h}$ cells were harvested, protein isolated and subjected to western blot analysis using the indicated antibodies. Equal sample loading was confirmed by Ponceau $\mathrm{S}$ staining and $\beta$-actin analysis.

Cdc25 phosphatases (Cdc25A, B and C) through the activation of cyclin-dependent kinases (Cdks) (15). Treatment with $15 \mu \mathrm{g} /$ $\mathrm{ml}$ petroleum ether extract resulted in a transient up-regulation of the phosphatases Cdc25A and Cdc25B followed by a substantial down-regulation (Fig. 3). In contrast, Cdc25C levels continuously decreased and correlated with the G2-M arrest after $8 \mathrm{~h}$. The entry of eukaryotic cells into mitosis is regulated by the phosphorylation level of Tyr15 of Cdk1 (16) through Weel and its antagonist Cdc25C. Phosphorylation of Cdk1 was reduced after $8 \mathrm{~h}$ and below detection after $24 \mathrm{~h}$, which is indicative for its activation. The reduced phosphorylation level of Cdk1 was not due to Cdc25C activity but to inhibited Weel expression and this may have helped to overcome the initial G2-M arrest. Subsequently, the tilting of orchestrated cell cycle signalling and in particular the down-regulation of S-phase specific Cdc25B was most likely responsible for S-phase arrest after $24 \mathrm{~h}$.

The petroleum ether extract inhibits proto-oncogene expression and induces DNA checkpoints. c-Myc has a profound impact on cell proliferation, differentiation and apoptosis and cyclin D1 promotes transition from G1 to S-phase. The up-regulation of the proto-oncogenes c-Myc and cyclin D1 is common for many

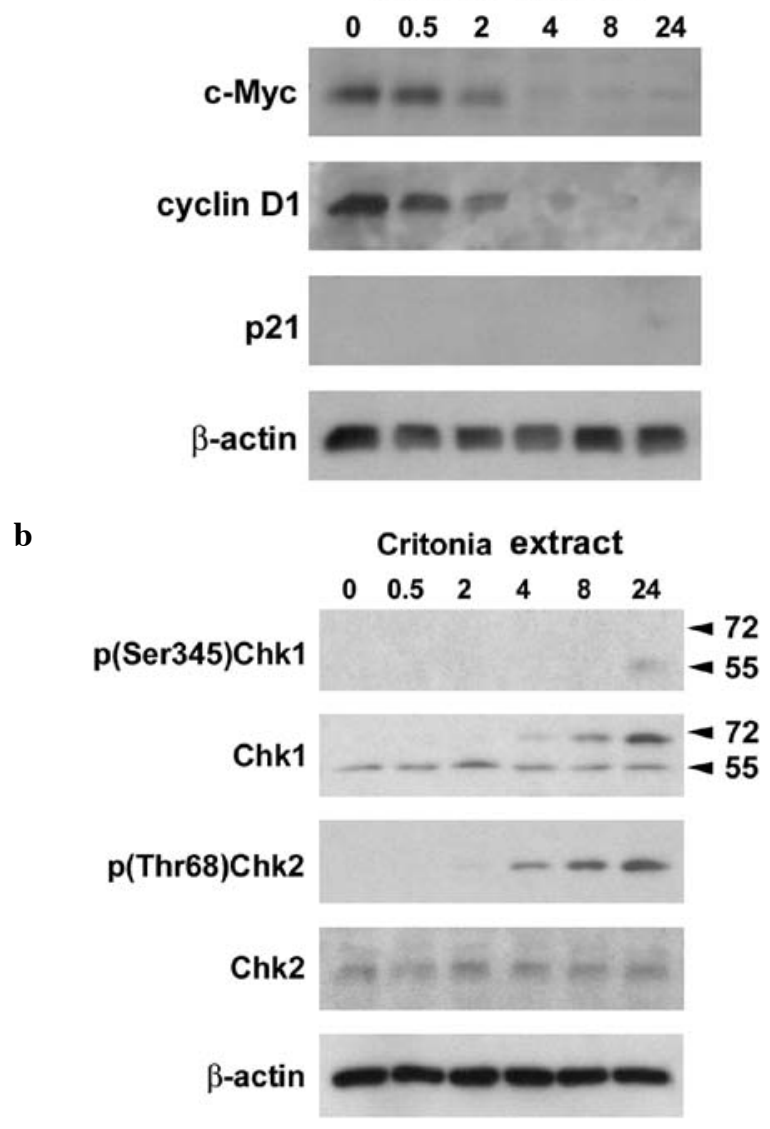

Figure 4. (a) Alteration in the expression of the proto-oncogenes c-Myc and cyclin D1 and the tumor suppressor p21 and (b) activation of checkpoint kinases 1 and 2 in HL-60 cells. HL-60 cells $\left(1.8 \times 10^{5}\right.$ cells $\left./ \mathrm{ml}\right)$ were treated with $15 \mu \mathrm{g} /$ $\mathrm{ml}$ petroleum ether extract of $C$ morifolia and after $0.5,2,4,8$ and $24 \mathrm{~h}$ cells were harvested, protein isolated and subjected to western blot analysis using the indicated antibodies. After $4 \mathrm{~h}$ of treatment an additional band occurs above Chk1 at $72 \mathrm{kDa}$. This is presumably due to unidentified posttranslational modifications and it is not clear whether this activates Chk1. Equal sample loading was confirmed by Ponceau S staining and $\beta$-actin analysis.

tumour types and contributes to an abnormal proliferation rate $(17,18)$. Incubation of HL-60 cells with $15 \mu \mathrm{g} / \mathrm{ml}$ petroleum ether extract caused a simultaneous repression of c-Myc- and cyclin D1 levels after 30 min which became undetectable during the time course (Fig. 4a). The down-regulation of cyclin D1 in cooperation with Cdc25B might have arrested HL-60 cells at the G1-S boundary. Furthermore, we investigated whether the p21 tumour suppressor became up-regulated, which is often the case upon treatment with cell cycle inhibitory agents. The main transcription factor for $\mathrm{p} 21$ is $\mathrm{p} 53$. Although HL-60 cells are p53 deficient the up-regulation of p21 can be achieved through other pathways (19). Nevertheless, the extract did not induce p21 expression.

The effect of the extract on proto-oncogenes and cell cycle regulators was severe and for c-Myc, cyclin D1 and Cdc25C it was also rapid. This tempted us to analyse whether DNA checkpoints became activated as a response to stressed DNA. When the DNA is damaged checkpoint kinases 1 and 2 (Chk1 and Chk2) are main mediators of cell cycle arrest to allow DNA repair prior to mitosis, or apoptosis in case of irreparable damage (20). Extract treatment did not change protein expression levels of 
a

C. morifolia
Petroleum ether extract

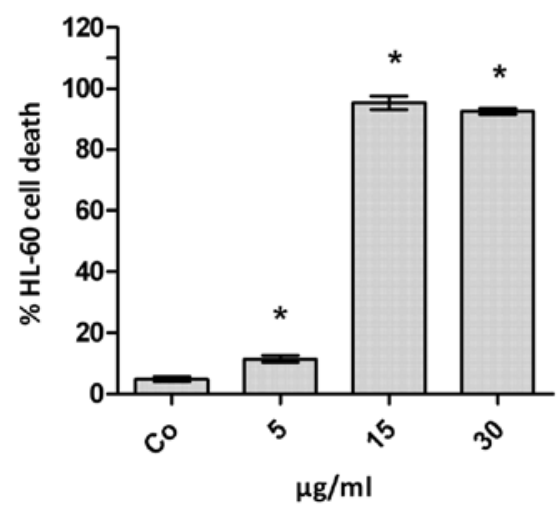

\section{b C. morifolia} Dichloromethane extract

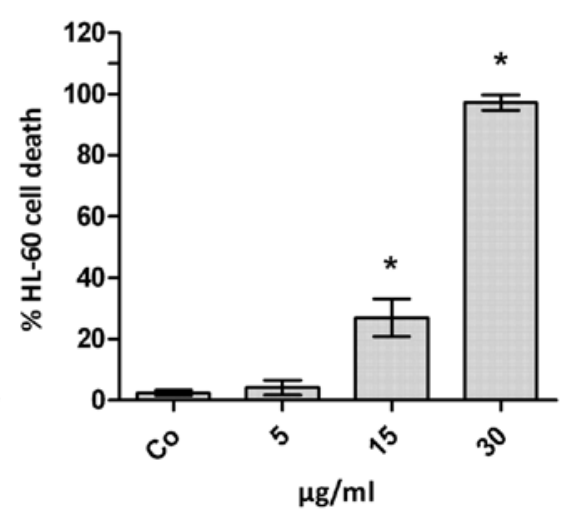

Figure 5. Induction of apoptosis in HL-60 cells. HL-60 cells $\left(10^{5}\right.$ cells $\left./ \mathrm{ml}\right)$ were seeded and allowed to grow for $24 \mathrm{~h}$ and then incubated with the indicated concentrations of (a) petroleum ether- and (b) dichloromethane extract for another $24 \mathrm{~h}$. Afterwards cells were stained with propidium iodide and Hoechst 33258 and examined with a fluorescence microscope equipped with a DAPI filter to count apoptotic and viable cells. Experiments were performed in triplicate. Error bars indicate $\pm \mathrm{SD}$, and asterisks significant alterations (in percent) compared to control $(\mathrm{p}<0.05)$.

Chk1 and Chk2 during $24 \mathrm{~h}$ but it caused the phosphorylation of Chk2 at the activating Thr68 within $4 \mathrm{~h}$ and the phosphorylation level further increased within $24 \mathrm{~h}$ (Fig. 4b). This correlated with the accumulation of cells in S-phase at this time-point which is consistent with the role of Chk2 in S-phase arrest $(21,22)$. Activated Chk2 was reported to phosphorylate the Cdc25A phosphatase on Ser177 targeting it for proteasomal degradation (23), as observed after $24 \mathrm{~h}$ of drug treatment (Fig. 3). Chk1 typically induces G2-M arrest (24) and extract treatment induced the phosphorylation of Chk1 at the activating Ser345 after $24 \mathrm{~h}$. However, this did not correlate with the observed increase of cells in G2-M after $8 \mathrm{~h}$ of treatment.

Apolar C. morifolia extracts induce apoptosis of HL-60 cells. The activation of DNA checkpoints provides time to repair the damage or in case the machinery is overstretched the cell undergoes apoptosis. Therefore, we investigated whether extract- treated cells survive or die. Based on their cell cycleinhibitory properties the two most potent apolar extracts (petroleum ether- and the dichloromethane extract) were tested regarding their pro-apoptotic potential and HL-60 cells were subjected to increasing extract concentrations for $24 \mathrm{~h}$. Then, propidium iodide and Hoechst 33258 were added to the cells facilitating the distinction between viable, apoptotic and necrotic cells via visual examination. Petroleum ether extract $(5 \mu \mathrm{g} / \mathrm{ml})$ caused a slight induction of apoptosis in HL-60 and $15 \mu \mathrm{g} / \mathrm{ml}$ triggered signs of early apoptosis in $>90 \%$ of the cells (Fig. 5). This was also achieved with $30 \mu \mathrm{g} / \mathrm{ml}$ of the dichloromethane extract and therefore, this extract was approximately half as active as the petroleum ether extract. Hence, the petroleum ether extract was further studied by western blot analyses. The petroleum ether extract activated caspase- 3 indicated by its cleavage into a $17-\mathrm{kDa}$ fragment within $2 \mathrm{~h}$. Caspase-3 is the major executioner of apoptosis and proteolytically degrades target proteins (25) such as poly(ADP-ribose) polymerase (PARP), which is a $116-\mathrm{kDa}$ nuclear enzyme, into a $85-\mathrm{kDa}$ and an (invisible) $31-\mathrm{kDa}$ signature type fragment. Thus, cleavage of PARP serves as a

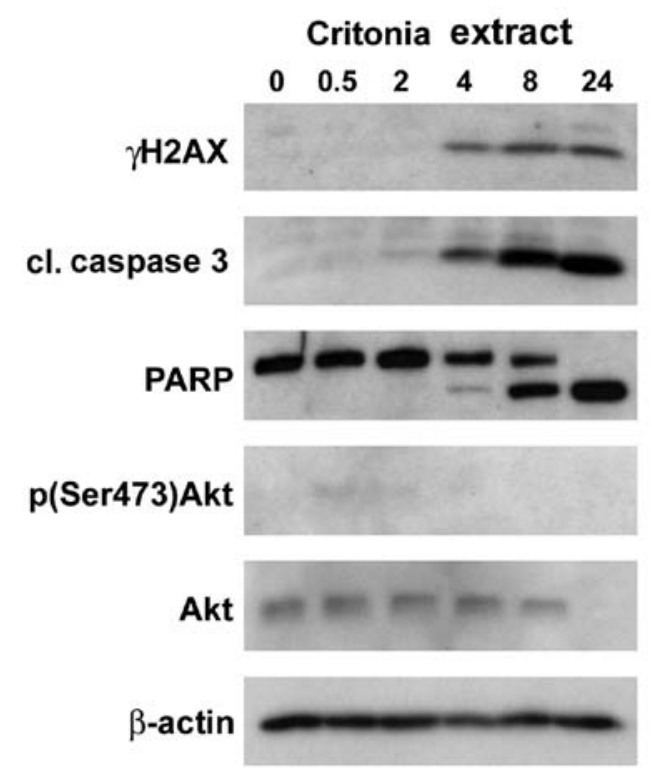

Figure 6. Induction of pro- and anti-apoptotic key proteins in HL-60 cells. HL-60 cells $\left(1.8 \times 10^{5}\right.$ cells $\left./ \mathrm{ml}\right)$ were treated with $15 \mu \mathrm{g} / \mathrm{ml}$ petroleum ether extract of $C$. morifolia and after $0.5,2,4,8$ and $24 \mathrm{~h}$ cells were harvested, proteins isolated and subjected to western blot analysis using the indicated antibodies. Equal sample loading was confirmed by Ponceau S staining and $\beta$-actin analysis.

marker of cells undergoing apoptosis which was observed after $4 \mathrm{~h}$ of treatment. Also the DNA becomes degraded, because caspase-3 cleaves and activates also the DNAse CAD. This leads to DNA double strand incisions, which are sensed by ATM, triggering the Ser139 phosphorylation of H2AX (which is called $\gamma-\mathrm{H} 2 \mathrm{AX}$ in the phosphorylated form) within minutes (26). Here we detected $\gamma$-H2AX after $4 \mathrm{~h}$ of treatment, which was subsequent to caspase-3 activation. Furthermore, we studied the expression of Akt, which plays a critical role in cell survival and is successfully tested as target in clinical trials [(27); http://clinicaltrials.gov/)]. This protein kinase 
Table II. Selectin E (SELE) expression in TNFa-induced HUVECs.

\begin{tabular}{|c|c|c|c|c|c|c|}
\hline \multicolumn{2}{|c|}{ Analysis } & \multirow{2}{*}{$\begin{array}{l}\text { Control } \\
\mathbf{0 . 0 5 6}\end{array}$} & \multirow{2}{*}{$\begin{array}{r}\text { TNF } \alpha \\
\mathbf{0 . 1 3 6}\end{array}$} & \multirow{2}{*}{$\begin{array}{c}\mathrm{TNF} \alpha \text { and } \\
10 \mu \mathrm{g} / \mathrm{ml} \\
\boldsymbol{C} \boldsymbol{r}-\mathrm{E}\end{array}$} & \multirow{2}{*}{ 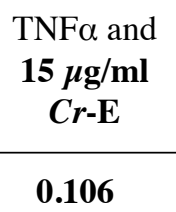 } & \multirow{2}{*}{$\begin{array}{c}\mathrm{TNF} \alpha \text { anc } \\
\begin{array}{c}20 \boldsymbol{\mu} / \mathrm{ml} \\
\boldsymbol{C r} \text {-E }\end{array} \\
\mathbf{0 . 1 0 6}\end{array}$} \\
\hline Inflammatory & SELE & & & & & \\
\hline reaction & (OD) & SD 0.001 & SD 0.003 & SD 0.013 & SD 0.001 & SD 0.024 \\
\hline \multirow[t]{2}{*}{ Cytotoxicity } & Calcein AM & 49.9 & 47.3 & 46.5 & 43.7 & 41.5 \\
\hline & $(\mathrm{OD})$ & SD 5.8 & SD 8.7 & SD 6.1 & SD 5.3 & SD 7.7 \\
\hline
\end{tabular}

HUVECs/well $\left(1 \times 10^{4}\right)$ were seeded into 96-well plates and grown to confluence. Indicated concentrations of $C$. morifolia petroleum ether extract $(\mathrm{Cr}$-E) were added $1 \mathrm{~h}$ prior to application of $10 \mathrm{ng} / \mathrm{ml} \mathrm{TNF} \alpha$ for another $4 \mathrm{~h}$. Then cells were fixed and SELE levels analysed by ELISA. In parallel, extracts were analysed by Calcein AM assay to monitor non-specific extract toxicity.

is an important downstream effector of the PI3K- and the mTOR pathway preventing apoptosis when activated by phosphorylation at the serine 473 residue $(28,29)$. In petroleum ether extract-treated HL-60 cells Akt did not become phosphorylated at Ser473 (Fig. 6) and the protein became down-regulated within $8 \mathrm{~h}$ and was undetectable after $24 \mathrm{~h}$. This certainly supported the apoptotic process initiated by caspase-3 activation and therefore the petroleum ether extract of C. morifolia contains a unique property blocking Akt expression.

Analysis of inflammatory response. C. morifolia was chosen because of its anti-inflammatory applications in the Maya traditional medicine. Here we show that the petroleum ether extract dose-dependently suppressed $\mathrm{TNF} \alpha$-induced SELE induction in HUVEC's (Table II), which supports the empirical observations of herbalists. Interestingly, the cytotoxic methanol extract of another anti-inflammatory remedy prepared of the rhizome of Smilax spinosa did not inhibit SELE induction (data not shown).

\section{Discussion}

Based on the traditional uses in Mayan medicine, an ethnomedical plant from Central America, C. morifolia, was investigated regarding its anti-carcinogenic activity. Conditions treated by extracts of the aerial parts of this plant range from parasitic ailments to various types of inflammation. Here, the latter was confirmed as SELE induction was inhibited. Oily preparations of $C$. morifolia leaves, which are enriched in apolar plant constituents are directly applied on severe skin damages with uncontrolled wound tissue growth (which is called cancer by the local population) (7). Despite its manifold curative usage in folk medicine, only little pharmacological research has been published on C. morifolia. Various sesquiterpene lactones and pyrrolizidine alkaloids (6), including a unique one named morifoline, were isolated (30) and we show that apolar, yet unidentified compounds of C. morifolia caused the degradation of cell cycle regulators and the down-regulation of the proto-oncogenes cyclin D1 and c-Myc. Cyclin D1 and c-Myc play an important role in the development of various cancer types $(17,18)$. D-cyclins bind to Cdk4 and Cdk6, thereby promoting the transition from G1 into S-phase (31,32). In addition, cyclin D1 regulates and associates with transcription factors in a Cdk-independent manner. Hence, the repression of cyclin D1 would suggest a cell cycle inhibition in G1 phase, which is in contrast with both the G2-M and the S-phase arrest observed upon extract treatment after 8 and $24 \mathrm{~h}$, respectively. Therefore, the extract blocked also another cell cycle regulatory mechanism which prevailed over the expected effect of cyclin D1 suppression.

Cdc25 dual specificity phosphatases are another mechanism regulating cell cycle transition. Whereas Cdc25A controls both the transit from G1 to S phase as well as that through G2-M phase $(33,34)$, Cdc25B seems to promote the entry from S phase into G2-M $(35,36)$. Cdc25C enables G2-M transit that can be compensated by Cdc25A (37), and recent studies suggest an undefined level of functional redundancy among Cdc25 phosphatases (34). The G2-M arrest observed after $8 \mathrm{~h}$ of treatment correlated with the down-regulation of Cdc25C, which (such as Cdc25A) regulates G2-M transition via activation of Cdk1 by de-phosphorylating Tyr15 $(15,16)$. Antagonizing the de-phosporylation, Weel kinase inhibits entry into mitosis by the phosphorylation of $\mathrm{Cdk} 1$ at the tyrosine 15 site (38). Weel phosphorylation at serine 642 leads to the nuclear-cytoplasmatic translocation and thus, to its inactivation since Weel becomes separated from its target. Noteworthy, after more than $8 \mathrm{~h}$ also Weel was repressed and hence, Cdk1 was maintained in an activated state and this may have enabled progression into S-phase. In S-phase, cells were arrested a second time, because meanwhile Cdc25B became degraded and Chk2 strongly activated (39). The activity of Chk1 and Chk 2 was reflected by the increased phosphorylation levels of Ser75 and Ser177 of Cdc25A, respectively $(23,40)$. The temporally separated effects on cell cycle inhibition were probably due to distinct anti-neoplastic compounds present in the petroleum ether extract.

Careful interpretation of the temporal succession of the observed effects (inhibition of cell cycle progression, repression of proto-oncogenes, and induction of apoptosis) suggested that the extract activity did not involve genotoxicity, because genotoxic events should have activated Chks first and then caspase-3 activation may follow. However, caspase- 3 was induced before the activation of Chk2 implicating that the extract was not damaging the DNA directly. 


\section{Acknowledgements}

We wish to thank Toni Jäger for preparing the figures and Professor J. Ulrichova for HUVEC cells. This work was supported by the Funds for Innovative and Interdisciplinary Cancer Research to M.F.-S. and G.K. and the Hochschuljubiläumsstiftung der Stadt Wien to G.K. grant nos. GACR (P505/11/1163) and ED0007/01/01 (both to M.S.) from the Centre of the Region Haná for Biotechnological and Agricultural Research are also gratefully acknowledged (L.R. and K.D.).

\section{References}

1. Cragg GM and Newman DJ: Natural Product Sources of Drugs: Plants, Microbes, Marine Organisms, and Animals. Comprehensive Medicinal Chemistry II, Chapter 1.08: 355-403, 2007.

2. Koehn FE and Carter GT: The evolving role of natural products in drug discovery. Nat Rev Drug Discov 4: 206-220, 2005.

3. Newman DJ and Cragg GM: Anticancer Agents from Natural Sources. Cragg GM, Kingston DGI and Newman DJ (eds). CRC Press/Taylor \& Francis, Boca Raton, FL, pp553-571, 2005.

4. Kinghorn $P$ and Fletcher $C$ : The relevance of higher plants in lead discovery programs. J Nat Prod 74: 1539-1555, 2011.

5. Li JW and Vederas JC: Drug discovery and natural products: end of an era or an endless frontier? Science 325: 161-165, 2009.

6. Herz W: Chemistry of the Critoniinae. Biochem Syst Ecol 32: 1159-1185, 2004.

7. Arvigo R and Balick M: Rainforest Remedies. 2nd edition. Lotus Press, Twin Lakes, WI, 1998.

8. Zhang JS, Nelson M, Wang L, Liu W, Qian CP, Shridhar V, Urrutia R and Smith DI: Identification and chromosomal localization of CTNNAL1, a novel protein homologous to alpha-catenin. Genomics 54: 149-154, 1998.

9. Strasser S, Maier S, Leisser C, Saiko P, Madlener S, Bader Y, Bernhaus A, Gueorguieva M, Richter S, Mader RM, WesierskaGadek J, Schott H, Szekeres T, Fritzer-Szekeres M and Krupitza G: 5-FdUrd-araC heterodinucleoside re-establishes sensitivity in 5-FdUrd- and AraC-resistant MCF-7 breast cancer cells overexpressing ErbB2. Differentiation 74: 488-498, 2006.

10. Maier S, Strasser S, Saiko P, Leisser C, Sasgary S, Grusch M, Madlener S, Bader Y, Hartmann J, Schott H, Mader RM, Szekeres T, Fritzer-Szekeres M and Krupitza G: Analysis of mechanisms contributing to AraC-mediated chemoresistance and re-establishment of drug sensitivity by the novel heterodinucleoside phosphate 5-FdUrd-araC. Apoptosis 11: 427-440, 2006.

11. Hüttenbrenner S, Maier S, Leisser C, Polgar D, Strasser S, Grusch $\mathrm{M}$ and Krupitza G: The evolution of cell death programs as prerequisites of multicellularity. Rev Mutat Res 543: 235-249, 2003.

12. Grusch M, Fritzer-Szekeres M, FuhrmannG, Rosenberger G, Luxbacher C, Elford HL, Smid K, Peters GJ, Szekeres T and Krupitza G: Activation of caspases and induction of apoptosis by amidox and didox. Exp Haematol 29: 623-632, 2001.

13. Gridling M, Stark N, Madlener S, Lackner A, Popescu R, Benedek B, Diaz R, Tut FM, Vo NTP, Huber D, Gollinger M, Saiko P, Özmen A, Mosgoeller W, De Martin R, Eytner R, Wagner KH, Grusch M, Fritzer-Szekeres M, Szekeres T, Kopp B, Frisch $\mathrm{R}$ and Krupitza G: In vitro anti-cancer activity of two ethno-pharmacological healing plants from Guatemala Pluchea odorata and Phlebodium decumanum. Int J Oncol 34: 1117-1128, 2009.

14. Madlener S, Svacinová J,Kitner M, Kopecky J,Eytner R,Lackner A, Vo NTP, Frisch R, Grusch M, De Martin R, Dolezal K, Strnad M and Krupitza G: In vitro anti-inflammatory and anticancer activities of extracts of Acalypha alopecuroidea (Euphorbiaceae). Int J Oncol 35: 881-891, 2009.

15. Hunter T: Protein kinases and phosphatases: the yin and yang of protein phosphorylation and signaling. Cell 80: 225-236, 1995.

16. Norbury C, Blow J and Nurse P: Regulatory phosphorylation of the p34cdc2 protein kinase in vertebrates. EMBO J 10: 3321-3329, 1991.

17. Dominguez-Sola D, Ying CY, Grandori C, Ruggiero L, Chen B, Li M, Galloway DA, Gu W, Gautier J and Dalla-Favera R: Non-transcriptional control of DNA replication by c-Myc. Nature 448: 445-451, 2007.
18. Fu M, Wang C, Li Z, Sakamaki T and Pestell RG: Minireview: Cyclin D1: normal and abnormal functions. Endocrinology 145: 5439-5447, 2004.

19. Abukhdeir AM and Park BH: P21 and p27: roles in carcinogenesis and drug resistance. Expert Rev Mol Med 10: e19, 2008.

20. Zhou BB and Elledge SJ: The DNA damage response: putting checkpoints in perspective. Nature 408: 433-439, 2000.

21. Koczor CA, Shokolenko IN, Boyd AK, Balk SP, Wilson GL and Ledoux SP: Mitochondrial DNA damage initiates a cell cycle arrest by a Chk2-associated mechanism in mammalian cells. J Biol Chem 284: 36191-36201, 2009.

22. Mazzacurati L, Pattacini L, Brusa G, Mancini M, Benvenuti M, Barbieri E, Martinelli G, Baccarani M, Greenberger JS and Santucci MA: Chk2 drives late G1/early S phase arrest of clonal myeloid progenitors expressing the $\mathrm{p} 210 \mathrm{BCR}-\mathrm{ABL}$ tyrosine kinase in response to STI571. Hematol J 5: 168-177, 2004.

23. Madlener S, Rosner M, Krieger S, Giessrigl B, Gridling M, Vo TP, Leisser C, Lackner A, Raab I, Grusch M, Hengstschläger M, Dolznig H and Krupitza G: Short 42 degrees $C$ heat shock induces phosphorylation and degradation of $\mathrm{Cdc} 25 \mathrm{~A}$ which depends on p38 ${ }^{\mathrm{MAPK}}$, Chk2 and 14.3.3. Hum Mol Genet 18: 1990-2000, 2009.

24. Liu Q, Guntuku S, Cui XS, Matsuoka S, Cortez D, Tamai K, Luo G, Carattini-Rivera S, De Mayo F, Bradley A, Donehower LA and Elledge SJ: Chk1 is an essential kinase that is regulated by Atr and required for the G(2)/M DNA damage checkpoint. Genes Dev 14: 1448-1459, 2000.

25. Fernandes-Alnemri T, Litwack G and Alnemri ES: CPP32, a novel human apoptotic protein with homology to Caenorhabditis elegans cell death protein Ced-3 and mammalian interleukin-1 beta-converting enzyme. J Biol Chem 269: 30761-30764, 1994.

26. Rogakou EP, Pilch DR, Orr AH, Ivanova VS and Bonner WM: DNA double-stranded breaks induce histone H2AX phosphorylation on serine 139. J Biol Chem 273: 5858-5868, 1998.

27. Yap TA, Yan L, Patnaik A, Fearen I, Olmos D, Papadopoulos K, Baird RD, Delgado L, Taylor A, Lupinacci L, Riisnaes R, Pope LL, Heaton SP, Thomas G, Garrett MD, Sullivan DM, de Bono JS and Tolcher AW: First-in-man clinical trial of the oral pan-AKT inhibitor MK-2206 in patients with advanced solid tumors. J Clin Oncol 29: 4688-4695, 2011.

28. Franke TF, Kaplan DR and Cantley LC: PI3K: downstream AKTion blocks apoptosis. Cell 88: 435-437, 1997.

29. Hers I, Vincent EE and Tavaré JM: Akt signalling in health and disease. Cell Signal 23: 1515-1527, 2011.

30. Wiedenfeld $\mathrm{H}$ and Cetto A: Pyrrolizidine alkaloids from Critonia morifolia. Phytochemistry 49: 1463-1465, 1998.

31. Pines J: Cyclins: wheels within wheels. Cell Growth Differ 2: 305-310, 1991.

32. Lingfei K, Pingzhang Y, Zhengguo L, Jianhua G and Yaowu Z: A study on $16, p R b$, cdk4 and cyclinD1 expression in non-small cell lung cancers. Cancer Lett 130: 93-101, 1998.

33. Hoffmann I, Draetta G and Karsenti E: Activation of the phosphatase activity of human cdc25A by a cdk2-cyclin E dependent phosphorylation at the G1/S transition. EMBO J 13: 4302-4310, 1994.

34. Kiyokawa $\mathrm{H}$ and Ray D: In vivo roles of $\mathrm{CDC} 25$ phosphatases: biological insight into the anti-cancer therapeutic targets. Anticancer Agents Med Chem 8: 832-836, 2008.

35. Nilsson I and Hoffmann I: Cell cycle regulation by the Cdc 25 phosphatase family. Prog Cell Cycle Res 4: 107-114, 2000.

36. Lammer C, Wagerer S, Saffrich R, Mertens D, Ansorge W and Hoffmann I: The cdc25B phosphatase is essential for the G2/M phase transition in human cells. J Cell Sci 111: 2445-2453, 1998.

37. Ferguson AM, White LS, Donovan PJ and Piwnica-Worms H: Normal cell cycle and checkpoint responses in mice and cells lacking $\mathrm{Cdc} 25 \mathrm{~B}$ and $\mathrm{Cdc} 25 \mathrm{C}$ protein phosphatases. Mol Cell Biol 25: 2853-2860, 2005.

38. McGowan $\mathrm{CH}$ and Russell P: Human Weel kinase inhibits cell division by phosphorylating $\mathrm{p} 34 \mathrm{cdc} 2$ exclusively on Tyr15. EMBO J 12: 75-85, 1993.

39. Ahn JY, Schwarz JK, Piwnica-Worms H and Canman CE: Threonine 68 phosphorylation by ataxia telangiectasia mutated is required for efficient activation of Chk2 in response to ionizing radiation. Cancer Res 60: 5934-5936, 2000.

40. Mailand N, Falck J, Lukas C, Syljuâsen RG, Welcker M, Bartek J and Lukas J: Rapid destruction of human Cdc25A in response to DNA damage. Science 288: 1425-1429, 2000. 